\title{
OPTIMASI SUMBER KARBON DAN KONDISI FERMENTASI \\ PRODUKSI SELULOSA OLEH STRAIN BAKTERI Acetobacter lovaniensis (MGA 6, SLK 1)
}

\author{
Risa Umami \\ Fakultas Ilmu Tarbiyah dan Keguruan IAIN Mataram
}

\begin{abstract}
Abstrak
Dalam upaya memperoleh sumber karbon dan kondisi fermentasi selulosa yang paling sesuai oleh strain Acetobacter lovaniensis (MGA 6 dan SLK 1) dilakukan optimasi berbagai faktor fermentasi dengan metode statis. Optimasi sumber karbon dilakukan dengan berbagai cairan buah (nanas, mangga, jeruk, dan pepaya). Berdasarkan sumber karbon dan strain terbaik, selanjutnya dilakukan optimasi kondisi fermentasi yang meliputi konsentrasi sumber karbon, volume inokulum, pH, dan temperatur inkubasi. Penentuan produktivitas selulosa dilakukan pada kondisi optimum dan ditentukan dengan nilai yield. Hasil penelitian menunjukkan bahwa sumber karbon terbaik yaitu cairan buah nanas untuk strain MGA 6. Sumber karbon berupa cairan buah nanas dengan kondisi fermentasi yang optimum yaitu konsentrasi sumber karbon dengan perbandingan buah:air adalah 1:11/2, volume inokulum $10 \mathrm{ml}, \mathrm{pH}$ medium 6, dan pada temperatur inkubasi $30 \mathrm{oC}$. Produktivitas selulosa dengan sumber karbon berupa cairan buah nanas sebesar 4,41\%.
\end{abstract}

Kata kunci: Acetobacter lovaniensis, Gluconobacter oxidans, selulosa, sumber karbon, optimasi 


\section{PENDAHULUAN}

Selulosa yang dihasilkan oleh tumbuhan relatif kurang murni karena mengandung hemiselulosa, lignin, dan pektin (Wiegand \& Klemm, 2006; Kato dkk., 2007) sedangkan selulosa bakteri bersifat lebih murni sehingga dalam pemanfaatannya tidak diperlukan proses pemurnian terlebih dahulu seperti selulosa tumbuhan. Selain itu juga, selulosa bakteri memiliki karakteristik sifat fisikawi yang khas dan berbeda dengan selulosa tumbuhan yaitu dalam hal tingkat kemurnian dan kristalinitas, daya tarik mekanik, serta pengikatan terhadap air (Wiegand \& Klemm, 2006; Chawla dkk., 2009; McKenna dkk., 2009; Hungund \& Gupta, 2010) menyebabkan selulosa bakteri lebih banyak dikembangkan sebagai bahan baku industri.

Beberapa penelitian telah dilakukan dalam upaya mencapai produktivitas selulosa yang tinggi berdasarkan optimasi faktorfaktor yang mendukung pertumbuhan dan metabolisme Gluconacetobacter xylinus seperti sumber karbon, kadar gula, $\mathrm{pH}$, dan temperatur (Phunsri dkk., 2003; Tantrian dkk., 2005; Lee, 1999). Kurosumi dkk. (2009) memanfaatkan sumber karbon sari buah (jeruk, nanas, apel, pear, dan anggur) dengan menggunakan strain Acetobacter xylinum NBRC 13693 untuk meningkatkan keberhasilan produksi selulosa dalam skala industri sedangkan dalam penelitian ini memanfaatkan cairan buah busuk sebagaimana yang dilakukan oleh Kongruang (2008) dan Tahir dkk. (2008) menggunakan limbah buah nanas dalam produksi selulosa.

Tujuan penelitian ini adalah untuk mengetahui sumber karbon terbaik dan kondisi fermentasi optimum dalam hal konsentrasi sumber karbon, volume inokulum, $\mathrm{pH}$, dan temperatur yang dibutuhkan oleh Acetobacter lovaniensis(MGA 6 dan SLK 1) dalam menghasilkan selulosa dengan metode fermentasi statis. Adapun manfaat penelitian ini adalah diharapkan mampu meningkatkan produksi selulosa dengan memperhatikan faktor-faktor yang mempengaruhi produksi selulosa dalam skala industri. 


\section{METODE PENELITIAN}

\section{Bahan dan Preparasi Inokulum}

Sumber karbon yang digunakan dalam penelitian ini adalah buah busuk (nanas, pepaya, mangga, dan jeruk), dan air kelapa. Sedangkan strain yang digunakan yaitu Acetobacter lovaniensis (MGA 6 dan SLK 1). Preparasi inokulum yaitu $1 \mathrm{ml}$ kultur stok diinokulasikan ke dalam $10 \mathrm{ml}$ medium produksi air kelapa dalam tabung reaksi yang telah disterilkan dan diinkubasikan selama 3 hari. Inokulum dalam tabung reaksi kemudian diinokulasikan ke dalam $100 \mathrm{ml}$ medium produksi air kelapa dalam erlenmeyer berukuran $250 \mathrm{ml}$ dan diinkubasikan selama 3 hari. Tahap selanjutnya adalah preparasi inokulum yang digunakan untuk menginokulasikan medium yang berbeda yaitu $30 \mathrm{ml}$ inokulum yang berasal dari erlenmeyer tersebut diinokulasikan lagi ke dalam $300 \mathrm{ml}$ medium produksi air kelapa dalam erlenmeyer berukuran $500 \mathrm{ml}$.

\section{Medium Fermentasi}

Media fermentasi yang digunakan yaitu medium produksi air kelapa dan medium modifikasi HS (Hestrin \& Schramm) (Kurosumi dkk., 2009; Hungund \& Gupta, 2010). Medium produksi air kelapa ada 2 yaitu: i) preparasi inokulum: gula pasir $5 \%$, ammonium sulfat $0,5 \%(\mathrm{w} / \mathrm{v})$, dan $\mathrm{pH}$ 6. ii) medium fermentasi cairan buah dengan perbandingan buah : air (1:1), ammonium sulfat $0,5 \%(\mathrm{w} / \mathrm{v})$, dan $\mathrm{pH}$ 6. Sedangkan komposisi medium modifikasi HS untuk sumber karbon (cairan buah yaitu buah : air (1:1), gula murni $2 \%(\mathrm{w} / \mathrm{v})$ ), bactopepton $0,5 \%(\mathrm{w} / \mathrm{v})$, yeast extract $\quad 0,5(\mathrm{w} / \mathrm{v}), \mathrm{Na} 2 \mathrm{HPO} 40,27 \%(\mathrm{w} / \mathrm{v})$, asam sitrat 0,12\% (w/v), MgSO 4 . 7H2O 0,57\% (w/v), dan pH 6.

\section{Optimasi sumber karbon dan kondisi fermentasi}

Tahap awal dari penelitian adalah screening sumber karbon berupa cairan buah (nanas, jeruk, pepaya, dan mangga), dan strain terbaik yang mampu menghasilkan selulosa dengan produktivitas tinggi. Sumber karbon cairan buah mengacu pada medium produksi air kelapa dan medium modifikasi HS. Setelah mendapatkan sumber karbon (cairan buah), serta strain terbaik 
maka tahap selanjutnya adalah optimasi kondisi fermentasi dalam hal konsentrasi sumber karbon (cairan buah dengan perbandingan buah : air $(1: 1,1: 11 / 2,1: 2,1: 21 / 2)$, volume inokulum (5\%, 10\%, dan 15\% (v/v)), pH medium $(4,5$, dan 6), dan temperatur $(25 \mathrm{oC}, 30 \mathrm{oC}, 37 \mathrm{oC})$.

\section{Produksi selulosa dan penentuan produktivitas dalam kondisi optimum}

Produksi selulosa berdasarkan kondisi optimum untuk menghasilkan selulosa baik untuk sumber karbon cairan buah dengan menggunakan metode produksi statis dan agitasi sedangkan produktivitas selulosa ditentukan dengan nilai yield yang dihasilkan berdasarkan metode produksi statis.

\section{HASIL DAN PEMBAHASAN}

\section{Optimasi berbagai sumber karbon}

Produktivitas sumber karbon cairan buah (nanas, jeruk, pepaya, dan mangga) yang mengacu pada medium produksi air kelapa dan medium modifikasi HS yang paling maksimum dalam menghasilkan selulosa yaitu cairan buah nanas dengan strain A. lovaniensis (MGA 6 dan SLK 1) (Gambar 1). Strain ini juga mampu menghasilkan selulosa dalam jumlah maksimum pada sumber karbon karbon air kelapa dengan penambahan gula sukrosa 5\% (w/v).

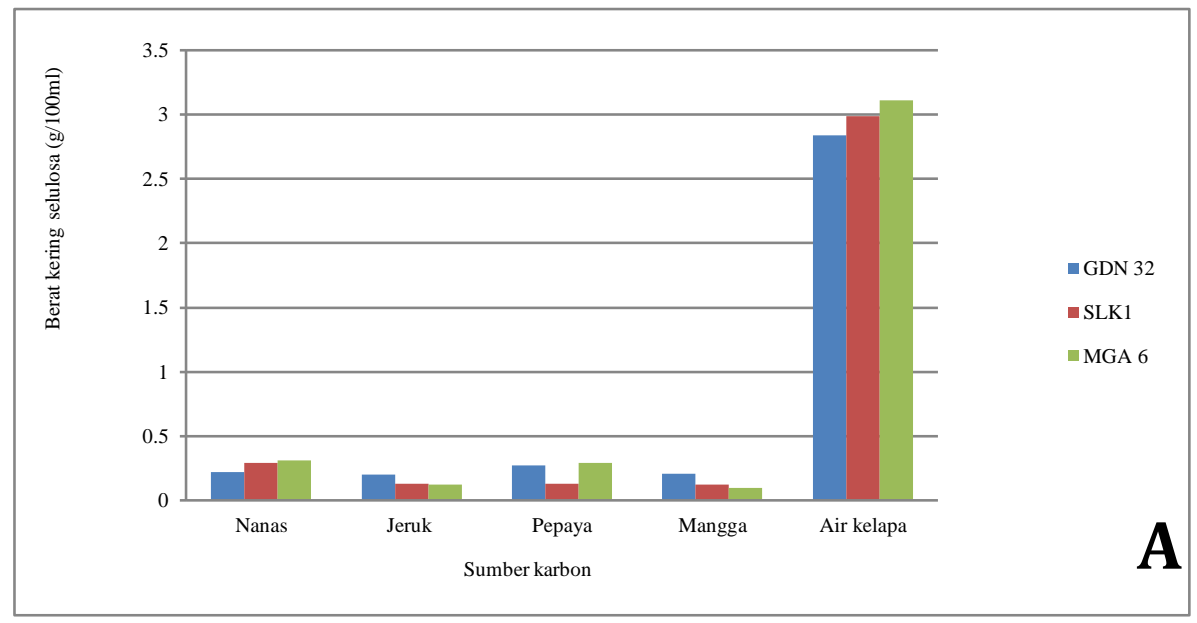

64 BIOTA: Jurnal Tadris IPA Biologi FITK IAIN Mataram 


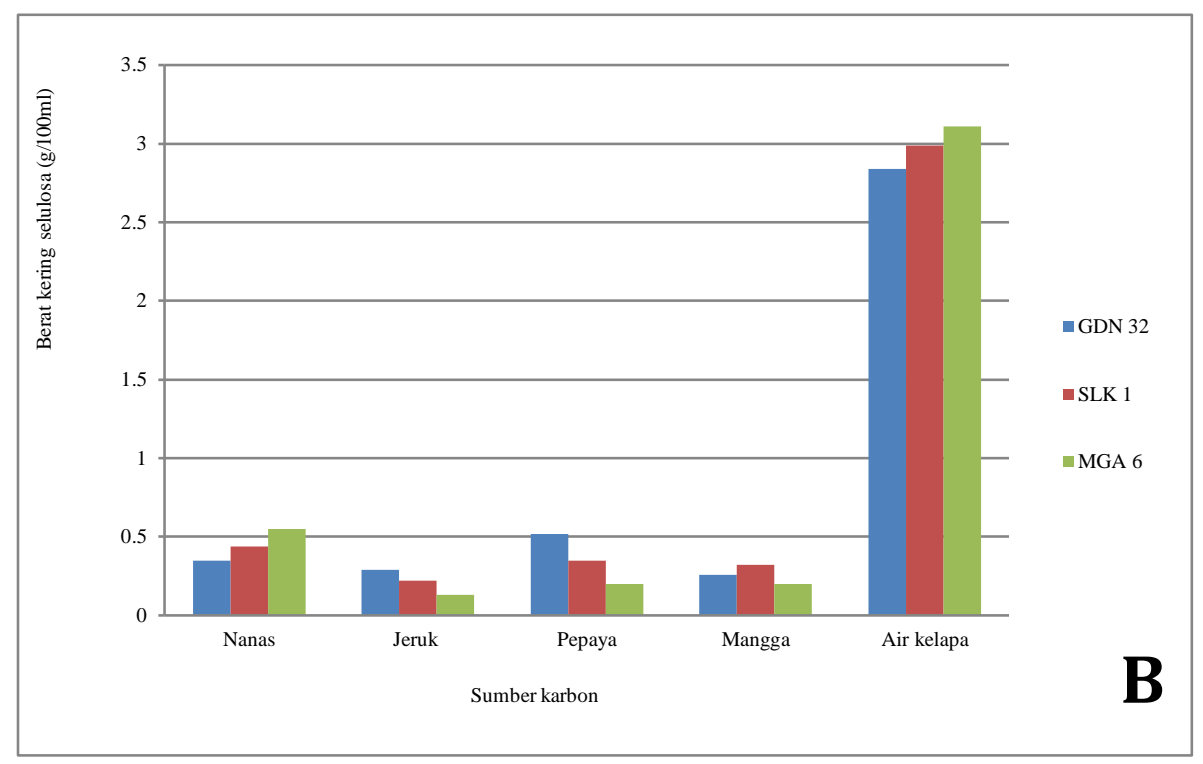

\section{Gambar 1}

Pengaruh sumber karbon cairan buah terhadap produksi selulosa yang mengacu pada medium standar produksi air kelapa (A) dan medium modifikasi HS (B)

Selulosa yang menggunakan sumber karbon beruapa cairan buah yang mengacu pada medium modifikasi HS menunjukkan produktivitas selulosa yang lebih tinggi bila dibandingkan dengan sumber karbon yang mengacu pada medium standar air kelapa. Adanya perbedaan tersebut kemungkinan disebabkan karena perbedaan komposisi medium yaitu medium cairan buah dengan standar produksi air kelapa hanya mengandung sumber nitrogen berupa ammonium sulfat sebesar 0,5\% (w/v) sedangkan medium modifikasi HS memiliki komposisi yang lebih kompleks dalam menunjang pertumbuhan A. lovaniensis (MGA6, SLK1).

Acetobacter lovaniensis (MGA 6) merupakan strain yang memiliki kemampuan menghasilkan selulosa dalam jumlah maksimum pada sumber karbon cairan buah nanas sebagaimana penelitian yang dilakukan oleh Hungund dan Gupta (2010) 
dengan Enterobacter amnigenus GH-1 yang menunjukkan hasil produksi selulosa untuk sukrosa sebesar $0,26 \mathrm{~g} / 100 \mathrm{ml}$ sedangkan untuk kelapa dan nanas masing-masing sebesar 0,33 dan 0,27 g/100ml.

\section{Optimasi kondisi fermentasi}

Tahap selanjutnya adalah optimasi kondisi fermentasi untuk sumber karbon berupa cairan buah nanas untuk A. lovaniensis (MGA 6) yang meliputi konsentrasi sumber karbon, volume inokulum, $\mathrm{pH}$ medium, dan temperatur. Berikut adalah gambar optimasi sumber karbon berupa cairan buah nanas dengan perlakuan konsentrasi sumber karbon dan volume inokulum. Strain A. lovaniensis (MGA 6) mampu menghasilkan selulosa dalam jumlah maksimum dengan konsentrasi sumber karbon paling optimum untuk cairan buah nanas yaitu 1:11/2 dengan volume inokulum $10 \%(\mathrm{v} / \mathrm{v})$.

Optimasi selanjutnya adalah pengaruh perlakuan $\mathrm{pH}$ dan temperatur terhadap produksi selulosa. Pengaruh perlakuan $\mathrm{pH}$ awal (4-6) untuk strain A. lovaniensis (MGA 6 dan SLK 1) menunjukkan bahwa kedua strain mampu menghasilkan selulosa pada rentang $\mathrm{pH}$ tersebut dengan $\mathrm{pH}$ optimum yang berbeda yaitu pH 6 untuk MGA 6 dan pH 5 untuk SLK 1 (Gambar 4A). 

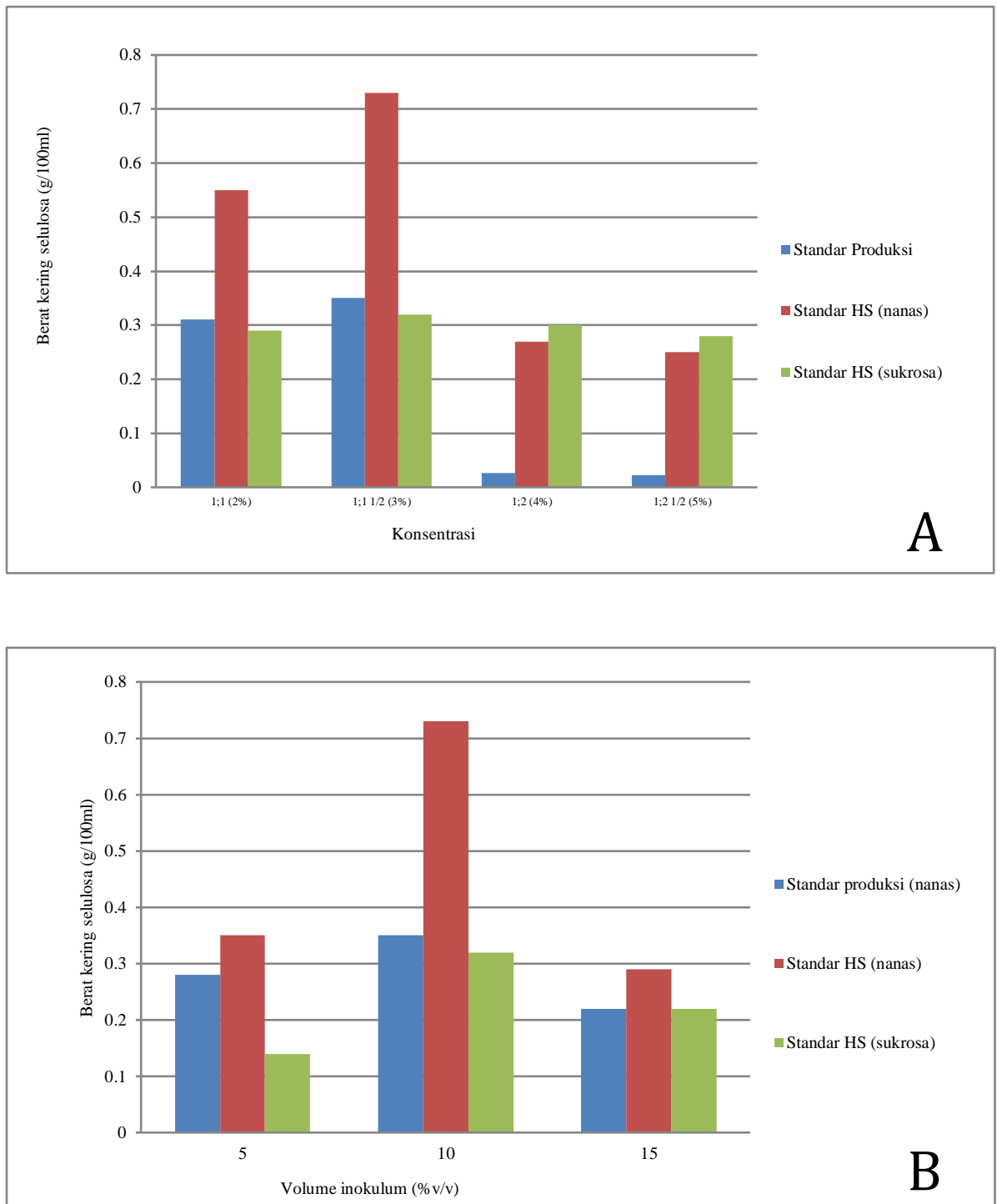

Gambar 2

Pengaruh $\mathrm{pH}$ medium (A) temperatur (B) dengan sumber karbon cairan buah (A. lovaniensis (MGA 6)); sukrosa (A. lovaniensis (SLK 1)) terhadap produksi selulosa. 
Demikian pula halnya dengan pengaruh temperatur inkubasi yang berbeda (25oC, $30 \mathrm{oC}$, dan $37 \mathrm{oC}$ ) tehadap produksi selulosa untuk strain tersebut menunjukkan temperatur optimum yaitu 30oC (Gambar 4B). Pada umumnya, rentang pH untuk produksi selulosa oleh G. xylinus (Acetobacter xylinum) yaitu dari 4-7 (Ross dkk., 1991) dan temperatur optimum untuk pertumbuhan G. xylinus yaitu berkisar 25-30oC (Aydin \& Aksoy, 2004).

\section{Produksi selulosa dan penentuan produktivitas dalam kondisi optimum}

Produksi selulosa dalam kondisi optimum menggunakan sumber karbon berupa cairan buah nanas dan sukrosa untuk strain A. lovaniensis (MGA 6 dan SLK1) dengan metode fermentasi statis dan agitasi menunjukkan bahwa produktivitas selulosa dengan metode fermentasi statis lebih tinggi dibandingkan dengan agitasi (Tabel 1). Hal ini disebabkan karena fermentasi secara agitasi banyak menimbulkan masalah yaitu munculnya mutan yang kehilangan kemampuan untuk memproduksi selulosa sehingga menyebabkan penurunan produksi selulosa secara keseluruhan (Lee, 1999; Czaja dkk., 2004).

\section{Tabel 1}

Berat kering selulosa dalam medium cairan buah dan gula murni dengan metode fermentasi statis dan agitasi

\begin{tabular}{|l|l|l|l|l|l|}
\hline \multirow{2}{*}{$\begin{array}{l}\text { Sumber } \\
\text { karbon }\end{array}$} & \multirow{2}{*}{$\begin{array}{c}\text { Medium } \\
\text { standar }\end{array}$} & \multicolumn{3}{|c|}{ Berat kering selulosa (g/100ml) } \\
\cline { 3 - 6 } & & \multicolumn{2}{|c|}{ Statis } & \multicolumn{2}{c|}{ Agitasi } \\
\cline { 3 - 6 } & MGA 6 & SLK 1 & MGA 6 & SLK 1 \\
\hline \multirow{2}{*}{ Nanas } & $\begin{array}{l}\text { Produksi } \\
\text { air kelapa }\end{array}$ & 0,35 & - & 0,153 & - \\
\cline { 2 - 6 } & HS & 0,73 & - & 0,41 & - \\
\hline Sukrosa & HS & - & 0,35 & - & 0,053 \\
\hline
\end{tabular}

Penentuan produktivitas selulosa dan konsumsi gula dari sumber karbon cairan buah nanas dan sukrosa dalam penelitian ini berdasarkan metode fermentasi statis.Kandungan gula pada 
sumber karbon cairan buah nanas maupun sukrosa setelah fermentasi berkurang (Tabel 2). Adanya perbedaan konsumsi glukosa, fruktosa, maupun sukrosa oleh strain MGA 6 dan SLK1 karena kemampuan setiap strain dalam mensintesis dan melakukan polimerasi glukosa menjadi selulosa berbeda (Keshk \& Sameshima, 2005).

\section{Tabel 2}

Kadar gula sumber karbon sari buah dan sukrosa yang diuji dengan High Performance Liquid Chromatoghraphy (HPLC)

\begin{tabular}{|l|l|l|l|l|}
\hline \multirow{2}{*}{ Gula yang diuji } & \multicolumn{4}{|c|}{ Konsentrasi (mg/L) } \\
\cline { 2 - 5 } & Sebelum Fermentasi & \multicolumn{2}{|c|}{ Setelah fermentasi } \\
\cline { 2 - 5 } & Nanas & Mangga & $\begin{array}{l}\text { Nanas } \\
\text { (MGA 6) }\end{array}$ & $\begin{array}{l}\text { Sukrosa } \\
\text { (SLK 1) }\end{array}$ \\
\hline Glukosa & 53553,92 & 1055,66 & 2129,28 & - \\
\hline Fruktosa & 55681,60 & 22625,84 & 2268,60 & - \\
\hline Sukrosa & 56361,68 & 1055,66 & 2146,72 & 16581,02 \\
\hline
\end{tabular}

Produktivitas selulosa bakteri dengan sumber karbon cairan buah nanas memiliki produktivitas yang berbeda dengan sumber karbon sukrosa. Strain A. lovaniensis (MGA 6) merupakan strain yang memiliki kemampuan produktivitas berupa yield selulosa paling tinggi dan efisiensi produksi dalam menghasilkan selulosa yaitu masing-masing $4,41 \%$ dan $4,58 \%$ bila dibandingakan dengan strain A. lovaniensis (SLK1) yaitu 11,67\% dan 26,12\% (Tabel 3). 


\section{Tabel 3}

Produktivitas selulosa bakteri dari sumber karbon nanas dan sukrosa dengan strain MGA 6 dan SLK 1

\begin{tabular}{|c|c|c|c|c|}
\hline $\begin{array}{c}\text { Sumber } \\
\text { karbon } \\
\text { (medium } \\
\text { HS) }\end{array}$ & $\begin{array}{c}\text { Berat } \\
\text { kering } \\
\text { selulosa } \\
\text { (g) }\end{array}$ & $\begin{array}{c}\text { Konsumsi } \\
(\%)\end{array}$ & $\begin{array}{c}\text { Yield } \\
\text { selulosa (\%) } \\
*\end{array}$ & $\begin{array}{c}\text { Efisiensi } \\
\text { produksi } \\
(\%) \\
* *\end{array}$ \\
\hline $\begin{array}{c}\text { Nanas } \\
\text { (MGA 6) }\end{array}$ & 0,73 & 96,09 & 4,41 & 4,58 \\
\hline $\begin{array}{c}\text { Sukrosa } \\
\text { (SLK 1) }\end{array}$ & 0,35 & 44,73 & 11,67 & 26,12 \\
\hline
\end{tabular}

* dihitung dari berat kering selulosaa dan berat sumber karbon tersedia

**dihitung dari berat kering selulosa dan berat konsumsi sumber karbon

\section{KESIMPULAN}

Dari penelitian yang telah dilakukan dapat simpulkan bahwa sumber karbon yang paling optimum dalam menghasilkan selulosa yaitu cairan buah nanas dengan strain A. lovaniensis (MGA 6), dengan konsentrasi sumber karbon cairan buah nanas yaitu bahan berbanding air adalah $1: 11 / 2$, volume inokulum $10 \%$ $(\mathrm{v} / \mathrm{v}), \mathrm{pH}$ medium 6 , temperatur $30 \mathrm{oC}$ dengan produktivitas selulosa berupa nilai yield dan efisiensi produksi yaitu masingmasing $4,41 \%$ dan $4,58 \%$.

\section{DAFTAR PUSTAKA}

Aydin, Y. Y. \& Aksoy, N. D. 2009. Isolation of Cellulose Producing Bacteria from Waste of Vinegar fermentation.Proceedings of the World Congress on Engineering and Computer science. I. October 20-22. Sun Fransisco. 
Castro, C., Zuluaga, R., Putaux, JL., Caro, G., Mondragon, I. \& Ganan, P. 2011. Structural Characterization of Bacterial Cellulose Produced by Gluconacetobacter swingsii sp. From Colombian Agroindustrial Wastes.Carbohydrate Polymers. 84: 96-102.

Chawla, P. R., Bajaj, I. B., Survase, S. A. \& Singhall, R. S. 2009. Microbial Cellulose: Fermentative Production and Application (review). Biotechnology. 47 (2): 107-124.

Czaja, W., Romanovicz, D. \& Brown, Jr. M. R. 2004. Structural investigations of microbial cellulose produced in stationary and agitated culture. Cellulose. 11: 403-411.

Huluwi, S. H. 2011. Tesis: Keanekaragaman Bakteri Penghasil Selulosa Pada Habitat Alami Buah (Anggur, Jeruk, Mangga, Salak) Dan Inokulum Nata. Yogyakarta, Universitas Gadjah Mada.

Hungund, B. S. \& Gupta, S. G. 2010. Production of Bacterial Cellulose from Enterobacter amnigenus GH-1 isolated from rotten apple. World Journal of Microbiology and Biotechnology. 26: 1823-1828.

Jonjankiat, S., Wittaya, T. \& Sridach, W. 2011. Improvement of Poly (Vinyl Alcohol) Adhesives With Cellulose Microfibre from Sugarcane Bagasse. Iranian Polymer Journal. 20 (4): 305317.

Kato, N., Sato, T., Kato, C., Yajima, M., Sugiyama, J., Kanda, T., Mizuno, M., Nozaki, K., Yamanaka, S. \& Amano, Y. 2007. Viability and Cellulose Synthesizing Ability of Gluconacetobacter xylinus Cells Under High-hydrostatic Pressure. Extremophiles. 11: 693-698.

Kai, A. \& Keshk, S. 1999. Nascent Structure of Microbial Cellulose by Acetobacter xylinum. Journal of Biochemistry. 58: 345352.

Keshk, S. A. M. S. \& Sameshima, K. 2005. Evaluation of Different Carbon Source for Bacterial Cellulose Production.African Journal of Biotechnology. 4 (6): 478-482.

Keshk, S.A. M. S., Razek, A. M. \& Sameshima, K. 2006. Bacterial cellulose production from beet molasses.African Journal of Biotechnology. 5 (17): 1519-1523. 
Kongruang, S. 2008. Bacterial Cellulose Production by Acetobacter xylinum Strains from Agricultural Waste Products. Applied Biochemistry and Biotechnology. 148:245-256.

Kurosumi, A., Sasaki, C., Yamashita, Y. \& Nakamura, Y. 2009. Utilization of various fruit juices for production of bacterial cellulose by Gluconacetobacter xylinus NBRC 13693. Carbohydrate Polymers. 76: 333-335.

Lee, C. H. 1999. Reduced Production by Microbial Cellulose caused by Aggregation of Acetobacter xylinum under Shaking Culture Conditions. Applied \& chemistry. 3(2):92-95.

Liu, CF., Ren, JL., Xu, F., Liu, JJ., Sun, JJ. \& Sun, RC. 2006. Isolation and Characterization of Cellulose Obtained From Ultrasonic Irradiated Sugarcane Bagasse. Journal Agriculture and food Chemistry. 54 (16): 5742-5749.

McKenna, A. B., Mikkelsen, D., Wehr, J. B., Gidley, J. M. \& Menzies, W. N. 2009. Mechanical and Structural Properties of Native and Alkalitreated Bacterial Cellulose Produced by Gluconacetobacter xylinus strain ATCC 53524. Cellulose. 16:1047-1055.

Nasab, M. M. \& Yousefi, A. 2010. Investigation 0f Physicochemical Properties of the Bacterial Cellulose Produced by Gluconacetobacter xylinus from Date Syrup. World Academy of Science, Engineering and Technology. 68: 1248-1253.

Park, S., Baker, J. O., Himmel, M. E., Parilla, P. A. \& Johnson, D. K. 2010. Cellulose Crystallinity index: Measurement Techniques and Their Impact on Interpreting Cellulase Performance. Biotechnology for Biofuels. 3: 1-10.

Phunsri, A., Tammarate, P., Krusong, W. \& Tantratian, S. 2003.The Liquid/Air Interface Area and Depth of Liquid Medium Suitable for Cellulose Production from Acetobacter TISTR 975.Journal of Science and Research Chulalongkorn University. 28 (1): 35-43.

Ratnayani, K., Dwi Adhi, N. M. A. \& Gutadewi, I G. A. M. A. S. 2008. Penentuan kadar glukosa dan fruktosa pada madu randu dan madu kelengkeng dengan metode kromatografi cair kinerja tinggi. Jurnal Kimia. 2 (2): 77-86. 
Ross, P., Mayer, R. \& Benziman, M. 1991. Cellulose Biosynthesis and Function in Bacteria. Microbiology Review. 55: 35-58.

Segal, L., Creely, J., Martin, A. \& Conrad, C. 1959. An empirical method for estimating he degree of crystallinity of native cellulose using diffractometer. Text Research of Journal. 29: 786-794.

Tahir, I., Sumarsih, S. \& Astuti, S. D. 2008.Kajian Penggunaan Limbah Buah Nenas local (Annanas comosus, L) Sebagai Bahan Baku Pembuatan Nata. Makalah Seminar Nasional Kimia XVIII, Jurusan Kimia Fakultas Matematika dan Ilmu Pengetahuan Alam. Yogyakarta.

Tantrian, S., Tammarate, P., Krusong, W., Bhattarakosol, P. \& Phunsri, A. 2005.Effect of Dissolved Oxygen on Cellulose Production by Acetobacter TISTR 975.Journal of Science and Research Chulalongkorn University. 30 (2): 179-186.

Wiegand, C. \& Klemm, D. 2006. Influence of Production Agent for Preservation of Gluconacetobacter xylinus on its Cellulose Production. Cellulose. 13: 485-492. 